\title{
The incorporation of ethical and bioethical rules in Law
}

\section{La incorporación de las reglas éticas y bioéticas en el Derecho \\ Alejandro Pacheco Gómez ${ }^{a}$}

\begin{abstract}
:
The ethics of the health professions and bioethics constitute a source for the legal norm, especially for those of health law. The provision of health services, eventually, due to its experimental and interventionist nature, can put at risk the legal assets of the person such as dignity, life and integrity, so that the obligations derived from ethics and bioethics, As a normative framework, they must be observed by health personnel.
\end{abstract}

Keywords:

Bioethics, law, ethics

\section{Resumen:}

La ética de las profesiones para la salud y la bioética constituyen una fuente para la norma jurídica, especialmente para las del derecho sanitario. La prestación de los servicios de salud, eventualmente, por su naturaleza experimental e intervencionista, pueden poner en riesgo bienes jurídicos de la persona como son la dignidad, la vida y la integridad, por lo que las obligaciones derivadas de la ética y la bioética, como marco normativo, deben ser de observancia para el personal de salud.

\section{Palabras Clave:}

Bioética, derecho, ética

\section{INTRODUCTION}

The aim of this work is to analyze and identify the incorporation of ethical, bioethical and scientific principles into Law.

Furthermore, medical obligations arise not only from legal provisions, but also to a large extent from scientific and ethical, and also bioethical principles. It is necessary to recognize and incorporate them into the legal system, to enable their mandatory observance.

Concerning moral, ethical, bioethical, and deontological norms, together with the law have an intimate relationship because as normative orders, they regulate human behavior. In other words, they establish duties for health personnel, with the difference that legal norms, due to their bilateral nature, allow the duty imposed to be demanded by a third party in the exercise of a subjective right. Thus, the rules derived from these normative orders converge in the definition of medical obligations.
The doctrine has formulated theories in this regard, based on legal logic, the philosophy of law, and in the light of the principles of the General Theory of Law. Jurists such as Kelsen, Radbruch, Pound, and Garcia Maynez have pronounced the need to generate "guidelines", "standards", or ethical criteria for the estimation of the behavior which are recognized and incorporated into the Law to regulate human behavior, given the impossibility for the legal system to exhaust all the cases that may arise.

It is important to mention that in the Mexican legal system, the observance of ethical and scientific principles in medical practice is derived from various legal provisions of health legislation. For example, the General Health Law stipulates that users shall have the right to ethically responsible services, and elsewhere that research on human beings shall be adapted to the ethical principles that justify it.

\section{ETHICS AND MORAL CONCEPTS}

The terms "ethics" and "morals" are often used as synonyms, which may be due to the similarity of their etymological 
meaning: "custom" from the Greek "ethos" and the Latin "mores", respectively.

Even though they have a similar grammatical origin, the doctrine has established their differences. On one hand, Morality has been defined as "the set of internal autonomous norms that regulate man's actions concerning good and evil". On the other hand, Ethics can be conceived "as the study or critical reflection of morality and human action". In this sense, morality becomes the object of the study of ethics.

Establishing a distinction does not necessarily lead to a separation. Both concepts are closely related and are also focused on the study, in a broad sense, of human behaviour

\section{CONCEPT OF LAW}

Providing a concept of "Law" is not easy, since the doctrine itself has not been able to unify the criteria of the leading jurists, since it is a term that has as many meanings as approaches to address it. It is frequently used as a synonym of justice, of normative order, of a set of faculties, to mention a few.

After an analysis of this term, Roscoe Pound (Pound, 1995, p. 49) stated that the three meanings given by jurists should be examined: the legal order, the body of norms or models, or authoritarian patterns of decision, whether judicial or administrative and the judicial procedure to which today we must add the administrative procedure.

With respect to law as a legal order, there are a set of rules created by an authority empowered to do so. Hence, these provisions are aimed at regulating conduct, which means, at provoking behavior. Therefore, it is a regime of social control of human conduct.

In this sense, it is important to identify that the rules and provisions, introduce the legal reasons by which the individual must behave. That is to say, it imposes duties that the person will fulfill outside of non-legal reasons that could argue against the ordered behavior. Thereby, it reduces the individual's options, making the ordered behavior obligatory.

However, it is not the only form in which the legal order or, in precise terms, normativity is expressed. Law also leads the individual by providing him/her with the legal possibility of performing or not performing some behavior. So doing, it refers to the granting of subjective rights or faculties to the individual.

From this guide, the legal order determines that the right or faculty linking legal consequences to its exercise. According to the legal logic, there are subjective rights that the individual can exercise or not, but also those whose omission is prohibited and therefore become duties.

Thus, the person might take into account these consequences, decide what to do. In either form, by imposing duties or granting rights, the legal order regulates human behavior.

It not only regulates the conduct of the governed but also of the organs legitimized to apply the law. The individual's freedom is limited so that to achieve social coexistence and to achieve the legal order. As for the organs of the State are granted the legal possibility to apply the law, determining their competence and providing them with powers, but they must be expressly empowered, otherwise, they are forbidden to act.

This legal order is created by bodies legitimized for this purpose. Moreover, the set of rules is coercive, which means that non-compliance generates a sanction. Strictly speaking, not all rules are punitive, for example, competition rules and adjudication rules - but they are all related to each other and form the legal order.

The second meaning, as a body of norms, Pound tells us (Pound, 1995, p. 51) that it is the body of authoritative materials. He states that it is the term most used by lawyers, and whose origin dates back to Roman law. In this sense, we can locate the objective law that we understand as the set of rules of a legal order.

Radbruch (Radbruch, G. 1993, p. 47), points out that it can be defined as the set of general and positive norms that regulate social life. So, we observe that law as a legal order is concretized in the norms issued by the competent state organs.

Lastly, the third meaning as a judicial procedure is illustrated by the Harvard master as the one to determine causes and controversies following authoritative guidelines, to defend the juridical order (Pound, R. 1995, p. 50). This also refers to adjective law, which is still part of the set of rules, but which will indicate how to apply the substantive law.

The relationship between the three meanings is evident, which facilitates the understanding of the meaning "Law". Under the subject we are dealing with, we will not dwell further in this section, since it is the subject of extensive work. With this, we intend to present" lato sens" the concept of Law.

\section{SOURCES OF LAW}

The sources of law refer to the origin of legal rules and the basis for their validity. These sources have been classified as follows:
A. Formal sources.
B. Real sources.
C. Historical sources.

\section{Formal sources:}

Formal sources are the processes of the formation of legal norms. Namely, legislation, jurisprudence, custom, and doctrine have been placed in this category.

In the first place, legislation is understood as the set of laws in force in a given place and time. Furthermore, it has been referred to as the procedure for their creation. In written law legal systems, it is probably the most relevant formal source.

Regarding the subject of this paper, this source is mainly constituted by health laws and civil law provisions, since the doctor-patient 
relationship is an authentic legal relationship between private individuals.

It is noteworthy that the issuance of laws concerning the provision of health care services is a federal competence, since in terms of articles 73, section XVI, of the Constitution and 3 of the General Health Law. It is a matter of general health. Nonetheless, given that it is a coincident and concurrent matter, such legislation may be applied by the federal entities.

Concerning Jurisprudence has two meanings. One is seen as the science of law and the other, as the set of criteria of interpretation and decision, established by the courts competent to issue them. The second one is the one that will be addressed.

In Mexico, it has been conceptualized as the interpretation of the law, firm, reiterated, and of mandatory observance, issued by the competent organs of the Judiciary.

In this regard, the Judiciary has issued, albeit few, criteria in which the right of the governed to health protection prevails as a constitutional guarantee, facilitating access to health services, especially medical care.

Referring to custom as a source of law has been considered as the customary procedure of creation of law, and as the result of that procedure, that is to say, the customary rule. Hence, it constitutes one of the formal sources other than legislation, jurisprudence, and doctrine.

Before the systems of written law, the custom was one of the main sources of law. Nevertheless, it cannot be concluded that this source is exclusive to unwritten law.

The customary rule is the result of the legal procedure of the creation of a set of repetitive acts of an enforcing body, which form a provision or a pattern of conduct, by the decision of said body to incorporate a specific case within the repetition of its acts, becoming applicable law; this refers to the fact that custom is given legal value and does not become law.

In this way, it can be seen that the ethical and scientific principles of medicine, many of them of customary origin, constitute "rules" or "guidelines" of behavior and that they are undoubtedly legal rules of an interpretative nature. It is self-evident that health law has a large component of customary rules.

With regard to doctrine, it is a set of concepts and ideas formulated by jurists and transmitted in the teaching of law, it is a dogmatic element for the study and application of the law. Even though it represents the work of legal scholars, and may influence the content of the rules, because it derives from the opinion of individuals, it lacks binding force.

Notwithstanding, the valuable contributions made by legal scientists can not be overlooked, since, as has been said, they can influence the author of the legislation and even the decision of the courts.

\section{Real sources}

The real sources of law are the factors and elements that determine the content of such rules (García. E. 2001, p. 51). In other words, the facts and human activity influence the content of these provisions.

As for the precepts that regulate the acts of health protection, especially medical care, medical work, the activities of commissions and committees in health matters, constitute real sources for the health law. For instance, commissions, and committees issue criteria, many of them of a bioethical nature, which undoubtedly influence decisions at the time of evaluating the medical act.

\section{Historical sources}

They include all those ancient documents that contain normative provisions. Some examples are the Code of Hammurabi, the Novo-Hispanic law, just to mention a few.

In health law, countless texts are containing these provisions. These include the Hippocratic Oath, Deuteronomy, Leviticus, Maimonides' prayer, and the sanitary precepts of Aztec law.

Many of these sources also contain ethical aspects for medical practice that, in addition to being actual sources, are customary provisions that have influenced health legislation.

\section{BIOETHICS AS SOURCE OF LAW}

To approach the concept of this discipline, it is necessary to refer to its etymological origin. From the Greek bios - life - and ethiké - ethics -, the confluence of biology and deontology, science, and conscience can be seen with medium clarity.

This term was coined by Van Renssselaer Potter (Albarellos, 2007 , p. 3). With this, he sought to create a link between biological facts and ethical values. Additionally, it is the ethical reflection, and action on biological life in its various manifestations, since it also studies issues such as technoscientific practice in animals, plants, and the environment. 
In this regard, Albarellos (Albarellos, 2007, p. 15) citing Llanos Zuluaga, notes a structure of bioethics as follows:

- Microbioethics: It aimed at the specific study of the ethical-medical relations established between doctor and patient. It will be the aspect most addressed in this work.

- Mesobioethics: It refers to the analysis of issues such as biomedical interventions at individual and group levels, genomic therapies, cloning, to mention a few.

- Macrobioethics: It studies issues such as population genetics, genetic pollution, and environmental problems.

The fundamental pillars of bioethics are ethics, law, and biotechnologies. The first with its contribution of the theory of the good, the second as a normative order, and the third as the manifestation of technoscience that radically modifies the system of life.

For a better understanding of this discipline, Albarellos (2007, p. 17), paraphrasing Beauchamp and Childress, mentions the four levels of justification of the disciplinary model of bioethics. For example, theories, principles, rules, and particular judgments. These levels are useful for the resolution of bioethical dilemmas in medical practice.

\section{Theories}

Theories give a foundation and qualify the results obtained and the purpose of human action. For the first case, objective theories are grouped, and for the second, subjective theories.

In this regard, the problem is to determine which applies to the specific case, since both theories have the same value. An example, the amputation of a leg due to necrosis would imply the impairment of the patient's integrity and could be considered a malicious act. On the contrary, if the result is to avoid the propagation of necrosis and save a life, it would be assumed as a moral act, applying to the objective theory.

The subjective theory would apply in the case of failure to stop the necrosis, but since the purpose of the medical act was aimed at this, the intervention is justified. In this case, both theories apply.

A situation in which one of the two predominates is when in an experimental study for a vaccine, a pathogenic agent is applied and an unfortunate result of infected people is obtained. Even though the purpose was to obtain immunization, the lavish result turns the act into a negative one.

It is understood that the assessment must be made on a case-bycase basis. For this reason, the prevailing criterion can be considered as a "rule" or "guideline" for subsequent cases.

\section{Principles}

As far as ethical principles are concerned, they are fundamentally aimed at:

- Beneficence.

- Non-maleficence.
- Autonomy.

- Justice.

Firstly, beneficence: is the presupposition in the actions of health personnel, since it is presumed that they will always seek the benefit of the patient, due to the ontology of the medical act; in general terms, the physician's beneficence is limited by the patient's need.

Secondly, non-maleficence, enshrined in the principle of medical ethics premium non-nocere, means that no harm will be caused to the patient. It is important to emphasize that in the application of medical treatments a permissible risk is assumed, since medicine is an inexact science, its harmlessness cannot be assured.

Nevertheless, the physician must observe the duty of care and must weigh the benefit and risk of the therapeutic measure, which will justify the assumption of the risk.

As for autonomy, also known as permission, it implies the capacity to decide for oneself, aware of the consequences, both positive and negative, of the indicated treatment; this principle is closely related to informed consent.

Ultimately, the principle of justice is applied when there is a conflict between the physician's principle of beneficence and the patient's principle of autonomy. It also operates in the accessibility to health services and the allocation of resources to institutions for adequate care.

Rules

The rules are derived from the principles. This means that the principles have a general character and are the basis for the issuance of the rules. They do not indicate treatment with greater risk than benefit is a rule derived from the principle of non-maleficence. These rules constitute the paradigm for action in bioethics. As a result, they are generated as "guidelines" or "standards" in the provision of medical care, which become interpretative legal rules when the medical act is judged.

Particular judgments

These represent the analysis of the real bioethical dilemmas faced daily in medical practice. It is the assessment of each particular case, following the rules that have been mentioned.

An example is when a married couple goes for consultation and the husband is diagnosed with a sexually transmitted infection and the doctor does not warn the wife of the situation. Although he knows of the risk of contagion, he is limited by respect for professional secrecy and the duty of confidentiality. The importance of rules in the study of these dilemmas is emphasized.

\section{LAW IN THE BIOETHICAL CONTEXT}

The interdisciplinary nature of bioethics means that its content is approached from different perspectives. Based on the aforementioned, we have seen how the theories, principles, and rules provide a valuable set of "guidelines" useful for the assessment of particular judgments. 
In this respect, the jurisdiction of bioethics has been confirmed by the issuance of several normative documents. As an example, we have the Universal Declaration of Human Rights and Bioethics, which was approved by the General Conference of UNESCO in 2005.

It is considered as the minimum that human beings have by the mere fact of being human beings, undoubtedly showing the important relationship between law and bioethics. Other normative texts are the Nuremberg Code (1947) and the subsequent Declarations of the World Medical Association: Helsinki (1964) and Tokyo (1975), to mention a few.

Bioethics indeed implies plurality and consensus, elements proper to a democratic society. In this area, the work of bioethics and research ethics committees and commissions becomes important. Regarding the latter, Article 104 of the Regulations of the General Health Law on health research stipulates that it will include persons of both sexes and professionals with the capacity to represent the moral, social, and cultural values of the research groups.

In these terms, the aforementioned commissions and committees are an ad hoc forum for informed debate and input from different points of view. Thus, the criteria they issue constitute guidelines of special interest. Similarly, serving as a basis for the analysis of the various dilemmas can contribute to the generation of public policies and regulations that reflect the feelings of society, bringing together different approaches and professional and cultural backgrounds.

As a consequence, it is necessary to develop standards to address the bioethical issues that arise.

The public authorities assume a great responsibility in this regard, not only because of the importance of biomedicine in the health of the population but also because of not ignoring scientific and technological progress, which is expressed as a benefit for society.

However, generating public policies involves the choice of a social model that may exclude others, but can not be resolved without prior consensus.

These are problems that do not entail a univocal meaning and therefore involve a question of legal axiology in determining which values are to be protected and how to do so.

It is impossible not to provoke conflicts within the social group. Consequently, the law must establish the limits of what is permitted for this purpose. From the above, it is clear that there is a great relationship between bioethics and law.

\section{REFERENCES}

Albarellos, L. (2007). Bioethics with a legal background. Porrúa.

García Máynez, E. (2001). Introduction to the study of law. Porrúa.

García Máynez, E. (2006). Introduction to legal logic. Colofón.

García Máynez, E. (2007). Philosophy of Law. Porrúa. 